\title{
Incoming Editors for Politics and Religion Share New Plans for Journal
}

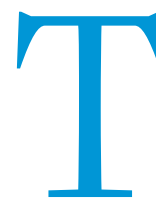

he APSA and the Organized Section on Religion and Politics announced new editors for the journal, Politics and Religion. Elizabeth A. Oldmixon, University of North Texas, will serve as lead editor; Mehmet Gurses, Florida Atlantic University, and Nicholas Tampio, Fordham University, will serve as editors. Their five-year editorial term commenced January 2017.

"To raise the profile of religion and politics scholarship in the discipline, we encourage the timely publication of accessible yet rigorous scholarship," explains Oldmixon. "In particular, the journal will now accept the submission of shorter, problem-driven manuscripts of approximately 4,500 words, in addition to the longer form pieces currently published in the journal. These would not be research notes, per se, as we would have an expectation of theoretically informed work, but a premium would be placed on strong, parsimonious writing." The editors also plan to develop special issues on timely topics such as the religion and the carceral state or religion and human rights.

The journal of the APSA's Religion and Politics section, Politics and Religion is a standard bearer for work in this subdiscipline, across subfields and methodological approaches. The editors seek to uphold the academic and scholarly standards of excellence cultivated by the first two editorial teams. They are strongly committed to publishing articles that represent the theoretical, methodological, and substantive diversity that characterizes the subdiscipline.

"The incoming editorial team submitted an excellent application," Elizabeth Shakman Hurd, Northwestern University, and Erin K. Wilson, University of Groningen, explained. "As an executive committee, we were particularly impressed with their ideas and innovations, such as blogging on topical articles, to increase the impact of the high-quality research produced by members of our section and subdiscipline of religion and politics more generally," they said. Hurd and Wilson believe that the editorial team's diverse array of interests and approaches can only help to ensure the continuing high standards of Politics and Religion as the section's flagship publication.

The journal was launched in 2007 and was edited by Ted G. Jelen, University of
Nevada, Las Vegas, and Sabrina P. Ramat, Norwegian University of Science and Technology. In 2012, Paul A. Djupe, Dennison University, and Angelia R. Wilson, University of Manchester, took over as editors for a five-year term.

\section{ABOUT THE EDITORS}

\section{Elizabeth A. Oldmixon}

Elizabeth A. Oldmixon (2001 PhD, University of Florida) serves as lead editor and manages American politics submissions. She is associate professor of political sci-


ence at the University of North Texas (UNT) and a fellow at the Schusterman Center for Israel Studies Summer Institute at Brandeis University. Oldmixon is formerly a Fulbright Scholar at University College Cork (2010), Ireland, and an American Political Science Association Congressional Fellow (2001-2002). With coauthor William Hudson, she won the 2006 Paul J. Weber Award for the best paper in religion and politics, and in 2010 the UNT Student Government Association named her an Honor Professor. She specializes in religion and legislative policymaking and political activism among clergy. She is author of Uncompromising Positions (Georgetown University Press 2005), coeditor of Mediating Religion and Government: Political Institutions and the Policy Process (Palgrave MacMillan 2014), and author of numerous articles and book chapters. Her work has appeared in Political Research Quarterly, Social Science Quarterly, Politics, Journal for the Scientific Study of Religion, Foreign Policy Analysis, and Politics and Religion, among other outlets.

\section{Mehmet Gurses}

Mehmet Gurses (2007 PhD, University of North Texas), editor for comparative politics and international relations submissions for the journal, is associate professor of political science at Florida Atlantic University. His research interests include ethnic and religious conflict, post-civil war peace building, post-civil war democratization, and the Middle East. His most recent project explores the transformative nature of civil war on the political and social culture of the civilian population. He is the coeditor of Con-

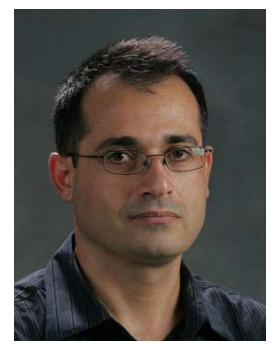
flict, Democratization, and the Kurds in the Middle East and has (co) authored more than two dozen articles and book chapters, which have appeared in such journals as International Interactions, Social Science Quarterly, Defense and Peace Economics, Democratization, International Studies Perspectives, Party Politics, Conflict Management and Peace Science, Political Research Quarterly, and Comparative Politics. His work on transnational ethnic kin and civil war outcomes was awarded Honorable Mention for Best Article in 2015 by the Political Research Quarterly.

\section{Nicholas Tampio}

Nicholas Tampio (2005 PhD, Johns Hopkins University), editor responsible for political theory submissions to the journal, is associate professor of political science at

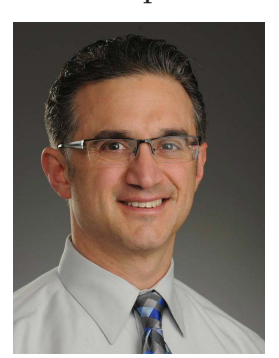
Fordham University. He has previously taught at the University of Virginia, George Mason University, and Hamilton College. His first book, Kantian Courage, considers the question of how to advance the Enlightenment in the contemporary political and philosophical context. The book has a chapter on how heirs of the Enlightenment ought to interpret Islamic political thought, which prompted him to write several articles on the topic. Tampio's second book was on the political vision of the French poststructuralist philosopher Gilles Deleuze. Tampio is presently writing a book on democracy and national education standards. In addition to publishing in journals such as the Political Theory, Journal of Politics, and Theory \& Event, he also writes for popular outlets such as Aeon and the Huffington Post. 